Int. J. Electrochem. Sci., 13 (2018) $6169-6189$

\title{
Biomass of Microalgae Spirulina Maxima as a Corrosion Inhibitor for 1020 Carbon Steel in Acidic Solution.
}

\author{
Larissa Soares Rodrigues, Anita Ferreira do Valle, Eliane D'Elia ${ }^{*}$ \\ Instituto de Química, UFRJ, Avenida Athos da Silveira Ramos 149, Centro de Tecnologia, Bloco A, \\ CEP 21941-909, Cidade Universitária, Rio de Janeiro, RJ, Brazil. Phone: +55 2139387816 \\ *E-mail: eliane@iq.ufrj.br
}

doi: $10.20964 / 2018.07 .11$

Received: 2 March 2018 / Accepted: 19 April 2018 / Published: 5 June 2018

In this paper, the biomass of the microalgae Spirulina maxima, a cyanobacterium that synthesizes high levels of protein, was studied as a natural inhibitor of the corrosion of carbon steel in $1 \mathrm{~mol} \mathrm{~L}^{-1} \mathrm{HCl}$ by weight loss measurements, potentiodynamic polarization curves, electrochemical impedance measurements and surface analysis by scanning electron microscopy (SEM). The biomass of the microalgae Spirulina maxima acted as a good corrosion inhibitor reaching an inhibition efficiency of $96.4 \%$ after $72 \mathrm{~h}$ of immersion for an inhibitor concentration of $100 \mathrm{mg} \mathrm{L}^{-1}$. The Ea increased with the addition of the inhibitor that characterizes the physical adsorption of the molecules present in the biomass of microalgae on the surface. This adsorption blocked the anodic and cathodic sites. The HMWF isolated from the total biomass showed an inhibition efficiency equal to the total biomass, which suggests that the macromolecules as proteins are probably responsible for the inhibitory action observed by the microalgae biomass.

Keywords: Acid Corrosion, Carbon Steel, Inhibitor, microalgae Spirulina maxima.

\section{FULL TEXT}

(C) 2018 The Authors. Published by ESG (www.electrochemsci.org). This article is an open access article distributed under the terms and conditions of the Creative Commons Attribution license (http://creativecommons.org/licenses/by/4.0/). 